\title{
FEDERAL VENUE REQUIREMENTS AND PROSECUTIONS FOR FALSE FILING*
}

DeFENDANTS in all federal prosecutions have the constitutional right to be tried in the judicial district where the alleged crime was committed. ${ }^{1}$ When the Government prosecutes in an improper venue, the court upon timely objection must dismiss the indictment. ${ }^{2}$ If the statute of limitations has run, the error will prevent further proceedings. ${ }^{3}$

Prosecutions involving the transmission of false statements to Governmental agencies have posed recurrent venue problems. ${ }^{4}$ It is now clear that trial may be held where the false information was received. ${ }^{5}$ And the defendant cannot be tried in the place where he did no more than prepare the document," or where he omitted to prepare a return required by law. ${ }^{7}$ But it is unsettled whether prosecution is proper in the district from which

*United States v. Valenti, 207 F.2d 242 (3d Cir. 1953) ; United States v. Lepkoff, 113 F. Supp. 551 (E.D. Tenn. 1953).

1. U.S. Const. Axrend. VI: "In all criminal prosecutions, the accused shall enjoy the right to a speedy and public trial, by an impartial jury of the State and district wherein the crime shall have been committed, which district shall have been previously ascertained by law. ..." (emphasis added). Similar language is contained in Art. III, $\$ 2$ of the Constitution.

2. United States v. Johnson, 323 U.S. 273 (1944); United States v. Liss, 137 F.2d 995 (2d Cir.), cert. denied, 320 U.S. 773 (1943); United States v. Moody, 102 F. Supp. 315 (W.D. Mo.), appeal dismissed, 195 F.2d 736 (8th Cir. 1952).

On the question of what constitutes timely objection, see, e.g., United States v. Zetill, 137 F.2d 845, 847 (2d Cir. 1943) ; Mahaffey v. Hudspeth, 128 F.2d 940, 942 (10th Cir.), cert. denied, 317 U.S. 666 (1942).

3. United States v. Borow, 101 F. Supp. 211, 215 (D.N.J. 1951). See also United States v. Valenti, 207 F.2d 242 (3d Cir. 1953) (3-year statute bars prosecution since affidavit filed in 1949).

4. For a general discussion of venue, see DobIE, HANDrOOK of FEJERAL JuRISDiction and Prockdure 510-13 (1928).

5. Shurin v. United States, 164 F.2d 566 (4th Cir. 1947), cert. denied, 333 U.S. 837 (1948) (false selective service information); Bowles v. United States, 73 F.2d 772 (4th Cir. 1934), cert. denied, 294 U.S. 710 (1935) (fraudulent income tax return); United States v. Eisler, 75 F. Supp. 634 (D.D.C. 1947), aff'd, 176 F.2d 21 (D.C. Cir.), ccrt. denied, 337 U.S. 958 (1949) (fraudulent passport application).

6. Reass v. United States, 99 F.2d 752 (4th Cir. 1938) (false statement to Federal Home Loan Bank); Wampler v. Snyder, 66 F.2d 195 (D.C. Cir. 1933) (fraudulent income tax return); United States v. Borow, 101 F. Supp. 211 (D.N.J. 1951) (false representations to War Assets Administration).

7. Rumely v. McCarthy, 250 U.S. 283 (1919) (omission to file alien property report); United States v. Lombardo, 241 U.S. 73 (1916) (omission to file Mann Act report); United States v. Commerford, 64 F.2d 28 (2d Cir.), ccrt. dcnicd, 289 U.S. 759 (1933) (omission to file income tax return). 
the accused mailed the untrue data. ${ }^{8}$ The Ninth Circuit has held the district of mailing proper venue, ${ }^{9}$ but there is Supreme Court dicta to the contrary. ${ }^{10}$

In the recent cases of United States $v$. Valcuti ${ }^{11}$ and United States $v$. Lepkoff, ${ }^{12}$ the Third Circuit and a federal district court in Tennessee each held that the district of mailing was improper venue. In the Valenti case the Government prosecuted a union leader for filing a false non-Communist affidavit with the NLRB. ${ }^{13}$ The evidence indicated that Valenti signed and swore to the affidavit in Camden, New Jersey, where he was tried and convicted. ${ }^{14}$ It was unclear how the affidavit reached the NLRB's main office in Washington, D.C. ${ }^{15}$ One judge in Valenti considered proper a prosecution in the district of mailing. ${ }^{18}$ But he, on the ground that the Government failed to prove the fact of mailing, ${ }^{17}$ concurred with the majority's reversal of the conviction. The two-judge majority held that venue was improper even if the mailing was presumed. ${ }^{18}$ Lepkoff involved fraudulent evasion of income taxes. ${ }^{10}$ Defendant mailed his returns in one judicial district of Tennessee to the tax director in another district of the same state. ${ }^{20}$ After indictment in the district

8. Several courts specifically view this as an open question. Shurin v. United States, 164 F.2d 566, 569-70 (4th Cir. 1947), cort. denicd, 333 U.S. 837 (1948); Reass v. United States, 99 F.2d 752, 755 (4th Cir. 1938); United States v. Borow, 101 F. Supp. 211, 215 (D.N.J. 1951).

9. Bridgeman v. United States, 140 Fed. 577 (9th Cir. 1905) (false claim to Commissioner of Indian Affairs).

10. "[O]ur attention has not been called to any case which decides that the requirement of a statute... that a paper be filed with a particular officer, is satisfied by a deposit in the post office at some distant place" United States v. Lombardo, 241 U.S. 73,78 (1916).

11. 207 F.2d 242 (3d Cir. 1953).

12. 113 F. Supp. 551 (E.D. Tenn. 1953).

13. The defendant filed his affidavit in accordance with the Labor Management Relations Act, 61 Stat. 146 (1947), 29 U.S.C. $\$ 159$ (h) (Supp. 1952). The Government prosecuted under the statute which forbids the maling of false statements "in any matter within the jurisdiction of any department or agency of the United States." 62 STAt. 749 (194\$), 18 U.S.C. § 1001 (Supp. 1952).

14. 207 F2d 242, 243-4 (3d Cir. 1953).

15. Since there was no regional office of the NLRB in Camden, the affidavit should have been sent to the Board's Philadelphia offee 29 Cons Fen. Ress. $\$ 101.3-$ (b) (1949); United States v. Valenti, 207 F.2d 242, 245 (3d Cir. 1953). The Board's affidavit officer testified that the affidavit had been mailed to Washington, but he did not know whether it had been mailed from Philadelphia or Camden. The union's secretary testified she did not remember what happened to the affidavit after it has been signed and sworn. Id. at 244-5.

16. Id. at 246 .

17. Id. at $246-7$.

18. Id. at 245. The Government had argued that the jury could infer from the evidence that the affidavit was mailed in Camden. Ibid.

19. The crime alleged was wilfully evading income tax payment by filing a false return. INT. Rev. Cone $\$ 145$ (b). For a discussion of the venue problem in income tax cases, see Wampler v. Snyder, 66 F.2d 195 (D.C. Cir. 1933).

20. 113 F. Supp. 551, 554 (E.D. Tenn. 1953). Although the defendant delivered some of his returns to the deputy tax director in his own judicial district, the court 
of receipt, he secured transfer of the case to the district of mailing where both his and many of the Government's witnesses resided. ${ }^{21}$ In Lepkoff the court retransferred the case to the district of receipt, which it held to be the only proper venue. ${ }^{22}$

Judges reach conflicting results in the "mailing" cases because they start their analyses at different points. Thus, the majority in Valenti rensoned that no crime was committed until the document reached the NLRB. ${ }^{23}$ Viewing the single element of receipt as essential to the crime of filing false information, they held that venue was proper only where the Government received the affidavit. ${ }^{24}$ Everything prior to receipt, including mailing, was irrelevant for venue purposes. ${ }^{25}$ But the concurring judge in Valenti first posited that the crime of filing, like other offenses, may have a "beginning." He argued that the defendant by mailing the afficlavit committed a sufficiently decisive act to constitute a "beginning." 27 When the Government received the document, the crime would be complete. He would, therefore, apply the "continuing offense" statute, which provides that crimes begun in one district and completed in another may be prosecuted in either district. ${ }^{28}$

Both approaches find support in the leading venue cases, ${ }^{20}$ and sometimes in the language of the same opinion. ${ }^{30}$ This anomaly arises because either

treated these returns as if they had been mailed to the tax director in the other judicial district. Id. at 554, 555-6.

21. The transfer was made "in the interest of justice" on the authority of FED. $R$. CRIMr. P. 21(b). See note 39 infra.

22. 113 F. Supp. 551, 556 (E.D. Tenn. 1953).

23. "While the matter may constitute the crime of perjury under state law, a false statement has not been made in a matter within the jurisdiction of the National Labor Relations Board, within the meaning of section 1001, until the affidavit throutgh its filing has become the basis for action by the Board." United States v. Valenti, 207 F.2d 242, 244 (3d Cir. 1953).

24. Id. at 244-5.

25. Id. at 245 .

26. Id. at 246 .

27. Ibid.

28. 62 STAT. 826 (1948), 18 U.S.C. § 3237 (Supp. 1952). The "continuing offense" statute also applies to offenses "committed in more than one district." Had Congress i11tended that only those offenses which were committed in two districts, i.c., were crimes in both, were to be covered by $\S 3237$, it would not have been necessary to include specifically the phrase "begun in one district and completed in another." See H.R. REP. No. 304, 80th Cong., 1st Sess. A161 (1947). This phrase would appear to be meaningless unless interpreted to cover those situations like Valenti or Lepkoff where the defendant has decisively committed himself in one district although the major element of the offense occurs in another. The Ninth Circuit apparently takes this view. Bridgeman v. United States, 140 Fed. 577 (9th Cir. 1905).

29. Compare Bridgeman v. United States, 140 Fed. 577 (9th Cir. 1905) (district of mailing false claim held proper venue), with Wampler v. Snyder, 66 F.2d 195, 196 (D.C. Cir. 1933) (dicta that district of mailing fraudulent income tax return improper).

30. Compare United States v. Lombardo, 241 U.S. 73, 77 (1916) (district of mailing proper venue within meaning of "continuing offense" statute), weith id. at 78 (suggesting district of mailing proper venue "would create revolutions in the procedure of the law...."). 
method of analysis will lead to the same result when the defendant personally delivers the false data or omits to file a required return. In these cases courts have argued that no crime is committed until receipt. ${ }^{32}$ Moreover, in these cases, there is no decisive act prior to receipt, upon which to peg venue. ${ }^{32}$ However, when the data is mailed, there is clearly a decisive act prior to receipt. 33 Therefore only in the "mailing" cases do the two rationales give conflicting results.

Forbidding prosecution in the district of mailing imposes an unnecessary burden on both the Government and defendant. People often file papers in distant Governmental offices. Thus, in the twenty states that have fewer tax districts than judicial districts, ${ }^{34}$ individuals in one judicial district may have to send their returns to another. ${ }^{35}$ Trials in the district of receipt may well entail the inconvenience and expense of transporting witnesses, lawyers, and records considerable distances. ${ }^{36}$ Such consequences conflict with the purpose of the constitutional provisions on venue. ${ }^{37}$ The drafters of the Constitution aimed at preventing trials far away from a defendant's evidence and friends. ${ }^{38}$

Even if both parties were willing to litigate in the district of mailing, the Valenti-Lepkoff rule would apparently deny them their choice. While Rule 21 (b) ${ }^{39}$ allows transfer of criminal cases for the convenience of the defend-

31. See, e.g., Rumely v. MICCarthy, 250 U.S. 283 (1919) (omission) ; Reass v. United States, 99 F.2d 752 (4th Cir. 1938) (personal delivery); United States v. Commeriord, 64 F.2d 28 (2d Cir.), cert. denied, 289 U.S. 759 (1933) (omission); United States v. Borow, 101 F. Supp. 211 (D.N.J. 1951) (personal delivery).

32. United States v. Valenti, 207 F.2d 242, 246 n.1 (3d Cir. 1953).

33. See, e.g., Hagner v. United States, 285 U.S. 427, 430-1 (1932); Salinger v. Loisel, 265 U.S. 224, 233-5 (1924) ; Reass v. United States, 99 F.2d 752, 755 (4th Cir. 1938).

34. These twenty states are: Alabama, Arlansas, Florida, Georgia, Illinois, Indiana, Iowa, Kentucky, Louisiana, Michigan, Mississippi, North Carolina, Olilahoma, South Carolina, Tennessee, Texas, Virginia, Washington, West Virginia, and Wisconsin. Alse, residents in the District of Columbia and Alaska have to file in Maryland and Washington, respectively. Data compiled from 3 P-H FED. TAx SEsv. III 21,340-56 (1953) and 112 F. Supp. vii-xv (1953).

35. Taxpayers must send their returns to the office in the tax district where they reside or where they have their principal place of business. I:*r. REv. Core $\$ \mathbf{5 3}$ (b) (1).

36. For a discussion of these considerations, see United States v. White, 95 F. Supp. 544 (D. Neb. 1951) ; United States v. National City Lines, 7 F.R.D. 393, 398 (S.D. Cal. 1947).

37. For an excellent historical analysis, see United States v. Parler, 19 F. Supp. 450 (D.N.J. 1937), aff'd, 103 F.2d 857 (3d Cir.), cort. denicd, 307 U.S. 642 (1939). Sce also Hyde v. Shine, 199 U.S. 62, 78 (1905).

38. Ibid.

39. "The court upon motion of the defendant shall transfer the proceeding as to him to another district or division, if it appears from the indictment or information or from a bill of particulars that the offense was committed in more than one district or division and if the court is satisfied that in the interest of justice the proceeding should be tranjferred to another district or division in which the commission of the offense is charged." FED. R. CRIMI. P. 21 (b). 
ant, the case may only be transferred to another district which has proper venue. ${ }^{40}$ Moreover, although Rule 20 allows a defendant to plead guilty in a district that would not otherwise be proper venue, ${ }^{41}$ no rule allows trial in such a district. ${ }^{42}$ And there is some doubt that such a rule would be constitutional. ${ }^{43}$

To avoid the burdens of the Valenti and Lepkoff holdings, other courts should permit prosecutions in the district of mailing. The "continuing offense" statute is the obvious doctrinal tool for achieving this result. If Valcnti and Lepkoff are widely accepted, Congress can easily reverse the trend by appropriate legislation. Such legislation should specifically define the particular crime of filing false data to include mailing the false information. ${ }^{44}$ Congress has acted in other instances when courts adopted a restrictive rule on vente. ${ }^{40}$

40. United States v. Erie Basin Metal Products Co., 79 F. Supp. 880 (D. Md. 1948); United States v. Hughes Tool Co., 78 F. Supp. 409 (D. Hawaii 1948); Holdsworth v. United States, 9 F.R.D. 198 (D. Me. 1949), appeal dismissed, 179 F.2d 933 (1st Cir. 1950).

41. "A defendant arrested in a district other than that in which the indictment or information is pending against him may state in writing, after receiving a copy of the indictment or information, that he wishes to plead guilty or nolo contendere, to waive trial in the district in which the indictment or information is pending and to consent to disposition of the case in the district in which he was arrested, subject to the approval of the United States attorney for each district." FED. R. CRIM. P. 20.

42. See United States v. Lepkoff, 113 F. Supp. 551, 556 (E.D. Tenn. 1953).

43. For the view that venue may be jurisdictional in certain cases and, therefore, cannot be waived, see United States v. Bink, 74 F. Supp. 603 (D. Ore. 1947). Other courts have treated venue as a personal privilege which defendants can waive. United States v. Gallagher, 183 F.2d 342 (3d Cir. 1950), cert. denied, 340 U.S. 913 (1951); Levine v. United States, 182 F.2d 556 (8th Cir. 1950), cert. devied, 340 U.S. 921 (1951).

44. The applicable statute could be redrafted as follows: "Whoever, in any matter" within the jurisdiction of any department or agency of the United States knowingly and wilfully falsifies, conceals or covers up by any trick, scheme, or device a material fact, or makes, or deposits or causes to be deposited in the mail provided the statcments or representations are received by the department or agency, any false, fictitious or fraudulent statements or representations, or makes or uses any false writing or document knowing the same to contain any false, fictitious or fraudulent statement or entry, shall be fined not more than $\$ 10,000$ or imprisoned not more than five years, or both." (additions to present statute, 18 U.S.C. $\S 1001$ (Supp. 1952), are italicized).

This statutory revision would probably allow income tax prosecutions in the district of mailing. The change would undercut the authorities upon which the Lepkoff holding is based.

45. See, e.g., Salinger v. Loisel, 265 U.S. 224, $233-5$ (1924) ; H. R. Rep. No. 304, 80th Cong., 1st Sess. A161 (1947) (discussing congressional reversal of United States v. Johnson, 323 U.S. 273 (1944). 